\title{
Structural Characterization of a Cyclodextrin/l-menthol Inclusion Complex in the Solid-state by Solid-state NMR and Vibrational Circular Dichroism
}

\author{
Takahiro SAKaI,* Yumiko AKagI,* Hisashi SuzukI,* Mitsuki IrIE,** Tetsuya NaKamura,* \\ Hisako SATO, $* * *$ and Izuru KAWAMURA**ं \\ *R\&D Center, T. Hasegawa Co., Ltd., 29-7 Kariyado, Nakahara, Kawasaki, Kanagawa 211-0022, Japan \\ **Graduate School of Engineering Science, Yokohama National University, 79-5 Tokiwadai, Hodogaya, \\ Yokohama, Kanagawa, 240-8501, Japan \\ ***Graduate School of Science and Engineering, Ehime University, 2-5 Bunkyo, Matsuyama, Ehime 790-8577, Japan
}

\begin{abstract}
Hydrophobic and volatile flavor molecules can be encapsulated inside cyclodextrins (CyDs). Inclusion complexes are frequently used in solid or dispersed states in preserved food and cosmetics. In this study, the solid-state structures of spray-dried inclusion complexes of $l$-menthol in $\alpha$-CyD and $\beta$-CyD were analyzed using ${ }^{13} \mathrm{C}$ solid-state NMR and vibrational circular dichroism (VCD). The NMR signals of $l$-menthol and CyDs were identified in the physical mixture and the $l$-menthol inclusion complex of $\alpha$ - and $\beta$-CyD. The NMR signal of the isopropyl-methyl group of menthol in the $\alpha$-CyD inclusion complex exhibited a large low-field shift, which suggested a steric hindrance between menthol and $\alpha$-CyD. VCD exhibited specific changes in the intensity of bands corresponding to $\mathrm{C}-\mathrm{C}$ vibrations in $\alpha$-CyD and $\mathrm{O}-\mathrm{C}$ stretching vibrations in $l$-menthol. Our results indicated that $l$-menthol specifically fitted the narrow space within $\alpha$-CyD. The combined solid-state NMR and VCD analysis provided structural insights into the flavor inclusion complex in the solid-state.
\end{abstract}

Keywords Solid-state NMR, VCD, cyclodextrin, $l$-menthol, inclusion complex

(Received April 7, 2020; Accepted June 12, 2020; Advance Publication Released Online by J-STAGE June, 19, 2020)

\section{Introduction}

The encapsulation of flavor molecules is essential for foods and cosmetic materials. ${ }^{1}$ Encapsulation techniques have been developed because most flavor compounds are hydrophobic and volatile. The encapsulation of various flavor molecules has been recently achieved. ${ }^{2-4}$ The preparation of powdered inclusion complexes of flavor compounds in cyclodextrins (CyDs) is important for the oxidation stability of these compounds during storage and for the controlled release of these flavor compounds from the powders. ${ }^{5,6}$ CyDs are cyclic oligosaccharides, which are constituted of $6-8$ glucopyranose units that are linked by $\alpha-(1,4)$ bonds; CyDs are versatile complexing agents, such as $\alpha-, \beta$-, and $\gamma$-CyD. They are characterized by a toroidal structure with a hydrophilic external surface and a sub-nanometer hydrophobic cavity (average internal diameter: $\alpha$-CyD: $0.57 \mathrm{~nm}, \beta$-CyD: $0.78 \mathrm{~nm}$, and $\gamma$-CyD: $0.95 \mathrm{~nm}$ ) (Fig. 1). These characteristics allow them to interact with various compounds, which results in a more enhanced solubility and stable inclusion of complex systems..$^{7,8}$ In addition, the inclusion of flavor compounds into CyDs by spray-drying has been studied well with respect to flavor release and physicochemical structure. ${ }^{9,10}$ CyDs possessing these

$\dagger$ To whom correspondence should be addressed.

E-mail: izuruk@ynu.ac.jp important properties can encapsulate small molecules in food and are used for drug delivery, cosmetics, and the scientific research of supramolecular structures. ${ }^{11-14}$ Structural insights into the flavor-CyD inclusion complex in the solid-state are important to understand how flavor molecules interact with CyDs. $l$-Menthol $[(1 R, 2 S, 5 R)-(-)$-menthol], which naturally occurs in peppermint oils, is a monoterpene that is present in mint oils, and induces a cooling sensation (Fig. 1). ${ }^{15-17}$ (a)

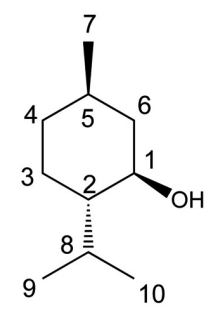

(b)

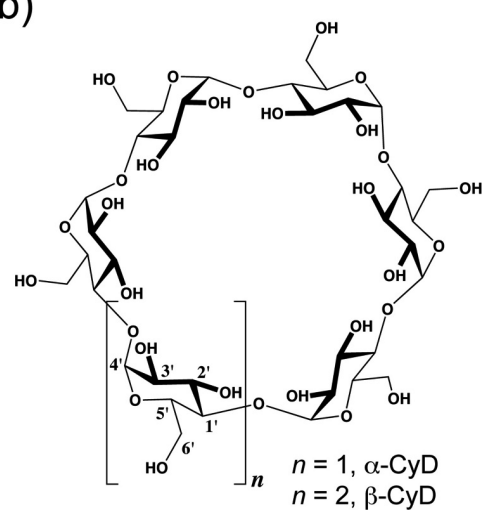

Fig. 1 (a) $l$-Menthol and (b) 6 and 7 glucose units for $\alpha$-and $\beta$-CyD. 
The asymmetric synthesis of $l$-menthol has been developed, and 1000 tons of $l$-menthol per year are industrially synthesized. ${ }^{18-20}$ The annual consumption of $l$-menthol as a flavorant in food and cosmetics is more than 7000 tons. ${ }^{15}$ It is difficult to preserve $l$-menthol by dissolving it in water because it is a volatile and hydrophilic compound. There have been many studies on the encapsulation of $l$-menthol. An $l$-menthol inclusion complex in $\beta$-CyD forms better encapsulation than in $\alpha$ - and $\gamma$-CyD to prevent flavor loss. ${ }^{21}$ The structural characterization with XRD and FTIR of an $l$-menthol inclusion complex in hydroxypropyl$\beta$-CyD prepared by freeze-drying confirmed that $l$-menthol entered the cavity of $\mathrm{CyD}$, which resulted in a slow release of menthol flavor. ${ }^{22,23} \quad l$-Menthol/hydroxypropyl- $\beta$-CyD $\quad(1: 1)$ inclusion complex nanofibers prepared by electrospinning enhance water solubility and thermal stability. ${ }^{24}$ Solid-state NMR experiments can provide the dynamic structure of various biological and food-related molecules. Thus, solid-state NMR is frequently used to study various complex systems, such as membrane proteins, raw biological samples, $\mathrm{Li}^{+}-\alpha$-CyD-PEO conduction systems, and food/drug-related inclusion complexes. ${ }^{25-28}$ The ${ }^{13} \mathrm{C}$ solid-state NMR technique using magic angle spinning (MAS) with a wide resonance range $(0-$ $220 \mathrm{ppm}$ ) can discriminate between the signals of CyD (host) and incorporated molecule (guest) in the solid state. ${ }^{28-33}$ In addition, chemical shifts are used to investigate the strength of hydrogen bonds and secondary structure on the basis of bond dihedral angles. Vibrational circular dichroism (VCD) determines the absolute configurations of chiral molecules, even in complex systems. ${ }^{34-36}$ VCD can observe characteristic intense signals and positive/negative signs depending on the crystal packing of amino acids, secondary structure of proteins, and the supramolecular chirality. ${ }^{37-41}$

Solid-state NMR allows one to determine the structure of target molecule in the solid-state at atomic resolution. ${ }^{42}$ VCD allows one to determine the absolute configuration of enantiomers and vibrational mode on the basis of intermolecular interactions. ${ }^{43}$ Especially, using well-resolved VCD and IR bands in the mid-infrared region at $1800-1200 \mathrm{~cm}^{-1}$, the structural analysis of chemical groups such as $\mathrm{CH}_{2}, \mathrm{OH}$ and $\mathrm{CONH}$ can be performed..$^{39,40}$ The combination of vibrational and solid-state NMR spectroscopies provides structural insights into complex molecular systems. ${ }^{44-46}$ The complementary use of Raman and solid-state NMR provided important structural insights of phospholipids into complexed cell membrane systems. ${ }^{44}$ The combined use of solid-state NMR and VCD found a $\gamma$-turn conformation of D-amino acid-containing tripeptide on the self-assembly. ${ }^{45}$ Here, using the well-known complex of $l$-menthol in CyD, the structure of the inclusion complex prepared by the spray-dried method was investigated in the solid-state by combining solid-state NMR and VCD.

\section{Experimental}

\section{Sample preparation}

$\alpha$ - and $\beta$-CyD were purchased from Wacker-Chemie. $l$-Menthol crystals were obtained from Sigma-Aldrich. A physical mixture was prepared with a menthol:CyD ratio of 4:6 using an agate mortar. To prepare the spray-dried sample, CyD (90 g) was mixed with $300 \mathrm{~mL}$ of deionized water, and gently stirred. Then, $l$-menthol $(10 \mathrm{~g})$ was added to the solution and homogenized at $8000 \mathrm{rpm}$ by a high-speed homogenizer (HOMO MIXER Mark II, PRIMIX).
Table 1 HPLC estimation of $l$-menthol content in cyclodextrins

\begin{tabular}{lcc} 
& Feed amount, $\%$ & Estimated content, $\%$ \\
\hline$\alpha$-CyD & 10.0 & 6.9 \\
$\beta$-CyD & 5.0 & 5.1 \\
& 10.0 & 8.9 \\
& 20.0 & 9.3 \\
\hline
\end{tabular}

\section{Spray-drying}

An inclusion complex of $l$-menthol in CyD was prepared from the described feed solution using a spray-dryer (L-8i, OHKAWARA KAKOKI). A fluid nozzle was used to atomize the feed solution using compressed air. The inlet $\left(150^{\circ} \mathrm{C}\right)$ and outlet $\left(90^{\circ} \mathrm{C}\right)$ temperatures of the air were strictly controlled with an electric heater. Spray-dried powders were collected from the outlet chamber.

\section{Polarizing microscopy}

The morphology of $l$-menthol inclusion complexes in $\alpha$ - and $\beta$-CyD was observed using a polarizing microscope (BX51, Olympus).

\section{HPLC analysis}

As a standard solution, $0.2 \mathrm{~g}$ of $l$-menthol crystals was dissolved in $50 \mathrm{~mL}$ of methanol $(\mathrm{MeOH})$. A total of $0.25 \mathrm{~g}$ of inclusion complexes in $\alpha$-CyD $(0.5 \mathrm{~g}$ in $\beta$-CyD) was mixed with $25 \mathrm{~mL}$ of ultrapure water and then diluted to a total of $50 \mathrm{~mL}$ in a measuring flask by adding $\mathrm{MeOH}$. The content of $l$-menthol in CyDs was determined using an HPLC (Shimazu Prominance) instrument equipped with an Inertsil ODS-2 column that was maintained at $40^{\circ} \mathrm{C}$ (Table 1). The eluent was acetonitrile $/ \mathrm{H}_{2} \mathrm{O}$ with a 1:1 ratio. The injection amount was $20 \mu \mathrm{L}$, and the flow rate was $1.0 \mathrm{~mL} / \mathrm{min}$.

\section{${ }^{13} \mathrm{C}$ solid-state NMR measurements}

${ }^{13} \mathrm{C}$ cross polarization magic angle spinning (CP-MAS) NMR experiments were performed at $25^{\circ} \mathrm{C}$, and the magic angle spinning frequency was adjusted to $12.0 \mathrm{kHz}( \pm 5 \mathrm{~Hz})$ on a $600 \mathrm{MHz}$ Bruker Avance III spectrometer with a 4.0-mm e-free probe. The contact time was adjusted to $1.0 \mathrm{~ms}$, and the spinal 64 proton decoupling of $81 \mathrm{kHz}$ was employed during acquisition. ${ }^{13} \mathrm{C}$ chemical shifts were referenced to the carbonyl resonance of adamantane at $38.480 \mathrm{ppm}$ [tetramethylsilane (TMS) at $0.0 \mathrm{ppm}]$.

\section{Vibrational circular dichroism (VCD)}

$l$-Menthol crystals, $\alpha$ - and $\beta$-CyD powders, and spray-dried $l$-menthol inclusion complexes in $\alpha$ - and $\beta$-CyD were prepared for VCD experiments by mixing each sample with $\mathrm{KBr}$ in the ratio of 0.9 to $120 \mathrm{mg}$ and placing the solid mixture in a transparent 10-mm-diameter pellet. VCD and infrared (IR) signals were recorded at $25^{\circ} \mathrm{C}$ on a JASCO PRSTO-S-2016 VCD/LD spectrometer. The IR intensity was adjusted to 0.7 - 1.0. The sample cell was rotated along the direction of monitoring at the angles of 0 and $45^{\circ}$ to confirm VCD reliability. The signals for each sample were accumulated for 10000 scans.

\section{Results and Discussion}

First, $l$-menthol crystals were characterized, as shown in Figs. 2 and 3. All ${ }^{13} \mathrm{C}$ NMR signals of $l$-menthol were identified with reference to those of $l$-menthol in $\mathrm{CDCl}_{3}{ }^{47-49}$ [Figs. 2(a) and 
(a)

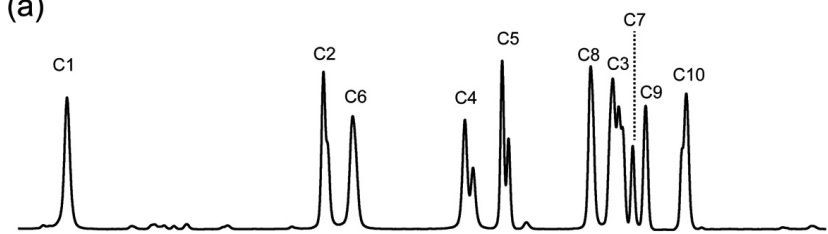

(b)

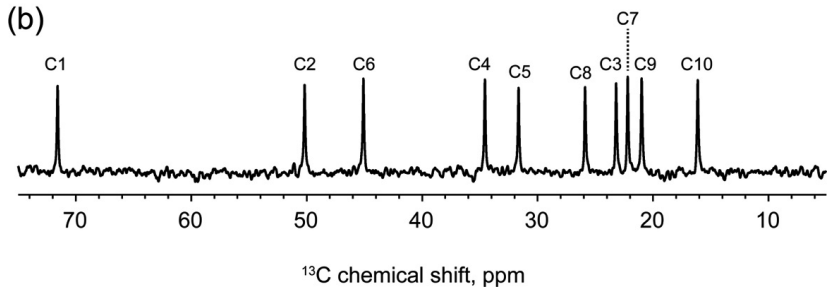

Fig. $2 \quad{ }^{13} \mathrm{C}$ NMR spectra of (a) $l$-menthol crystal and (b) $l$-menthol in $\mathrm{CDCl}_{3}$.

Table $2{ }^{13} \mathrm{C}$ chemical shifts of all ten carbons of $l$-menthol (TMS: $0.0 \mathrm{ppm}$ )

\begin{tabular}{llllll}
\hline & \multicolumn{5}{c}{$l$-Menthol } \\
& $\begin{array}{c}\text { In } \\
\text { solution }\end{array}$ & Crystal & $\begin{array}{c}\text { Physical } \\
\text { mixture }\end{array}$ & $\begin{array}{c}\alpha \text {-CyD } \\
\text { inclusion } \\
\text { complex }\end{array}$ & $\begin{array}{c}\beta \text {-CyD } \\
\text { inclusion } \\
\text { complex }\end{array}$ \\
\hline C1 & 71.22 & 70.75 & - & - & - \\
C2 & 50.5 & 48.52 & 51.28 & 51.37 & 51.15 \\
& & & 51.36 & 49.09 & \\
C3 & 23.17 & 23.48 & 23.73 & 24.83 & 24.23 \\
& & 22.96 & 23.9 & & \\
C4 & 34.7 & 36.29 & 36.93 & 36.22 & 35.9 \\
& & 35.59 & 35.59 & & \\
C5 & 31.79 & 33.06 & 32.42 & 32.21 & 32.65 \\
& & 32.51 & 32.7 & 31.47 & \\
C6 & 45.13 & 46.01 & 46.10 & 47.36 & 46.28 \\
& & & 46.11 & 45.87 & \\
C7 & 22.26 & 21.75 & 21.61 & 22.87 & 22.18 \\
& & & 21.89 & & \\
C8 & 25.60 & 25.39 & 26.60 & 25.76 & 26.46 \\
C9 & 21.1 & 20.63 & 19.14 & 21.49 & 21.63 \\
C10 & 16.01 & 17.11 & 16.62 & 20.74 & 16.81 \\
\hline
\end{tabular}

2(b), Table 2]. The separated signals of C2 - C5 of the crystal indicated polymorphs of a menthol cyclohexane skeleton. The $\mathrm{VCD} / \mathrm{IR}$ spectra of the $l$-menthol crystal in $\mathrm{KBr}$ are recorded in Figs. 3(a) and 3(b). Some sharp IR bands are observed around $1450 \mathrm{~cm}^{-1}$ (deformation C-H stretching); 1173, 1093, $1037 \mathrm{~cm}^{-1}$ (C-O stretching); $1367 \mathrm{~cm}^{-1}$ (O-H bending) in Fig. 3(b). Corresponding twelve VCD bands were identified and labeled as $\mathbf{1}$ - 12. To assign VCD bands, $l$-menthol was dissolved in $\mathrm{CCl}_{4}$ or used as a film. ${ }^{50}$ The VCD spectra of $l$-menthol crystals showed peaks that almost mirrored those of $d$-menthol $[1 S, 2 R, 5 S)$-(+)-menthol] in $\mathrm{CCl}_{4}{ }^{51,52}$ The weak band $\mathbf{1}$ at $1455 \mathrm{~cm}^{-1}$ was assigned to the isopropyl group deformation and methyl group symmetric or asymmetric deformation. The intense bands of 10 and 11 at $1049 \mathrm{~cm}^{-1}(-)$ and $1025 \mathrm{~cm}^{-1}(+)$ were assigned to the $\mathrm{C} 1-\mathrm{O}$ stretching mode and cyclohexane ring deformation, respectively.

The morphology of spray-dried samples was observed with an optical microscope, as shown in Figs. 4(a) and 4(b). The spraydried inclusion complexes in $\alpha$-CyD were needle-type crystals, (a)

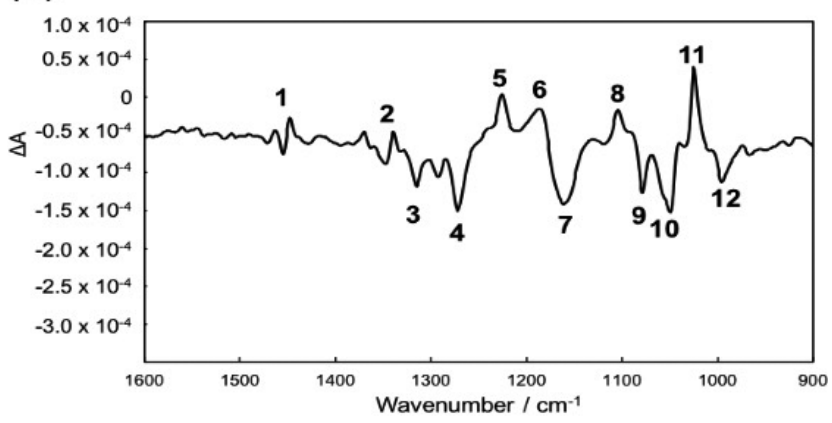

(b)

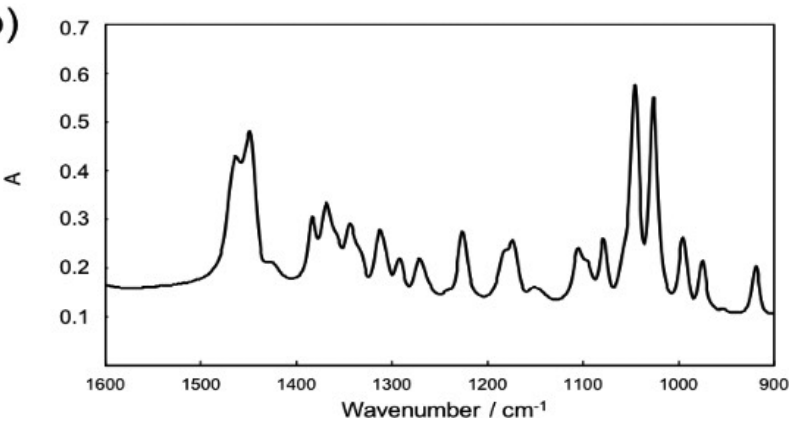

Fig. 3 (a) VCD and (b) IR spectra of the $l$-menthol crystal.

while $\beta$-CyD crystals showed a flat and elongated prism form. The HPLC analysis of $l$-menthol embedded in CyD is shown in Table 1 . The content of $l$-menthol determined in $\alpha$-CyD reached $6.9 \%$ with respect to the feed amount of $10 \%$. $\alpha-\mathrm{CyD}$, which has a smaller size cavity, formed an inclusion complex with $l$-menthol using the spray-dried method. $\beta$-CyD can include a larger amount of $l$-menthol, but it was saturated and reached the feed amount of $10 \%$. Thus, spray-dried samples prepared with a feed amount of $10 \%$ effectively formed $l$-menthol/CyD inclusion complexes, which were subsequently spectroscopically investigated with solid-state NMR and VCD.

The ${ }^{13} \mathrm{C}$ CP-MAS NMR spectra of $\alpha$-CyD were compared to those of $l$-menthol, the physical mixture of $\alpha$-CyD/l-menthol, and the inclusion complex of $10-\mathrm{wt} \% \quad l$-menthol in $\alpha$-CyD, as shown in Figs. 5(a) - 5(d). The NMR signals of six carbons $\mathrm{C1}^{\prime}-\mathrm{C}^{\prime}$ for one unit of $\alpha-\mathrm{CyD}$ are shown in Fig. 5(a) and Table 3. The resonances of $\mathrm{Cl}^{\prime}$ and $\mathrm{C}^{\prime}$ appeared at 103 and $82 \mathrm{ppm}$. Apart from the main resonance, the observed isolated signals of $\mathrm{C}^{\prime}$ and $\mathrm{C}^{\prime}$ of $\alpha-\mathrm{CyD}$ at 98.5 and $77.4 \mathrm{ppm}$ completely disappeared in the inclusion complex spectrum [Fig. 5(d)]. C $4^{\prime}$ and $\mathrm{C}^{\prime}$ signals of the inclusion complex emerged at $10-15 \mathrm{ppm}$. As reported, these signals depend on the six-fold symmetrical structure with respect to the dihedral angles for $\phi$ and $\psi$. The symmetrical complex signals for 169 and $-171^{\circ}$ corresponding to $\mathrm{C}^{\prime}{ }^{\prime}$ were observed at $101.9 \mathrm{ppm}$ and those corresponding to $\mathrm{C}^{\prime}{ }^{\prime}$ were observed at $80.9 \mathrm{ppm}$ (for sodium benzene sulfonate- $\alpha-\mathrm{CyD})$. Whereas the asymmetrical complex (e.g., $\mathrm{H}_{2} \mathrm{O}-\alpha-\mathrm{CyD}$ complex) signals for $160^{\circ} / 169^{\circ}$ and $-183^{\circ} /-150^{\circ}$ were observed at 99.3 and $102.9 \mathrm{ppm}$ for $\mathrm{C}^{\prime}$ and at 75.6 and $81.1 \mathrm{ppm}$ for $\mathrm{C}^{\prime}$, respectively. ${ }^{28,32,33}$ The asymmetric structure showed higher-field resonances of $\mathrm{C}^{\prime}$ and $\mathrm{C}^{\prime}$. Furthermore, $\mathrm{C}^{\prime}$ position signals are also very sensitive to gauche(-)-gauche (+) (asymmetrical crystals) (60.7 ppm for the $\mathrm{H}_{2} \mathrm{O}-\alpha$-CyD complex) or gauche $(+)$-trans (symmetrical crystals) (62.1 ppm for sodium benzene sulfonate- $\alpha-\mathrm{CyD}$ ) conformations, as viewed from the $\mathrm{C}^{\prime}-\mathrm{OH}$ orientation with respect to $\mathrm{C}^{\prime}{ }^{\prime}-\mathrm{C}^{\prime}$ and $\mathrm{C}^{\prime}-\mathrm{O} 5$ bonds. ${ }^{28,32,33}$ 
(a)

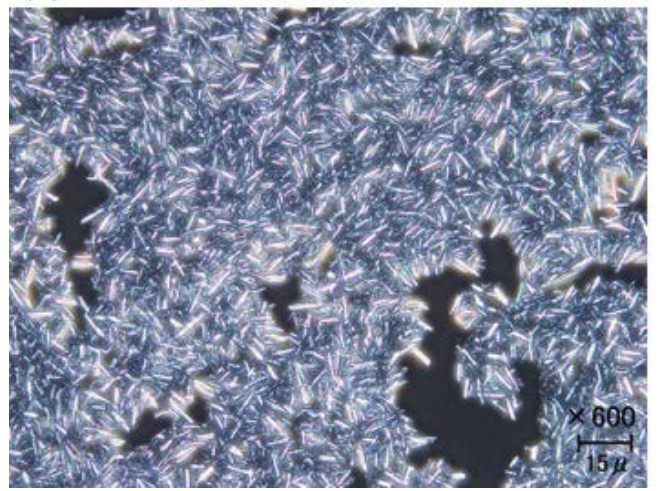

(b)

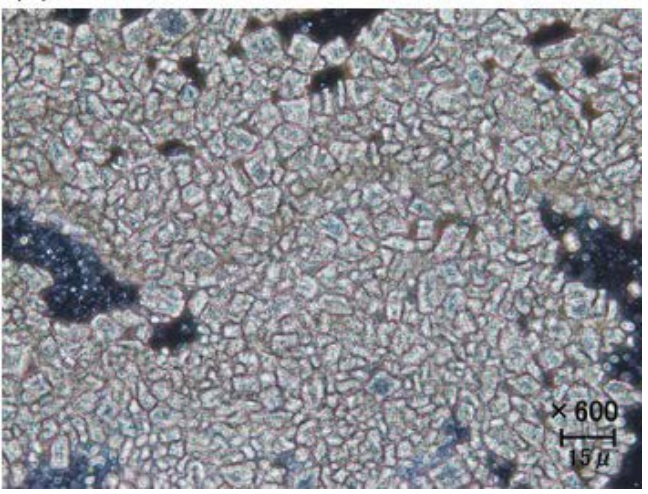

Fig. 4 Polarizing microscope images of (a) $\alpha$-CyD/l-menthol and (b) $\beta$-CyD/l-menthol inclusion complexes (scale bar $15 \mu \mathrm{m}$ ).

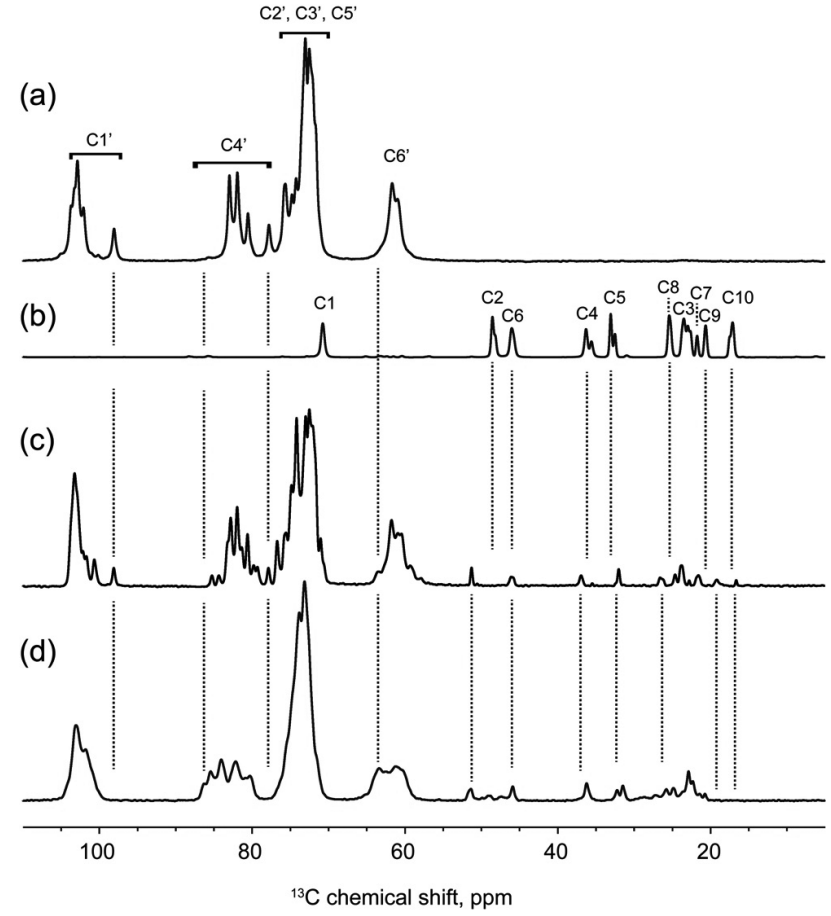

Fig. $5{ }^{13} \mathrm{C}$ CP-MAS NMR spectra of (a) $\alpha$-CyD, (b) $l$-menthol crystal, (c) $\alpha$-CyD/l-menthol physical mixture, and (d) spray-dried $\alpha$-CyD/l-menthol inclusion complex.

NMR results showed that $\alpha$-CyD formed an asymmetrical structure with internally bound water in the hydrophobic interior, while a symmetrical inclusion complex was generated with $l$-menthol in the interior.

In addition, the ${ }^{13} \mathrm{C}$ NMR signals of the $l$-menthol inclusion complex and physical mixture were identified, except for the $\mathrm{C} 1$ signal, which overlapped with the $\mathrm{C6}^{\prime}$ signals [Figs. 5(c) and 5(d), Table 2]. Interestingly, although the signals in the crystal and physical mixture appeared at 17.11 and $16.62 \mathrm{ppm}$, like in the $\mathrm{CDCl}_{3}$, the $\mathrm{C} 10$ signal of $l$-menthol only in the inclusion complex was shifted toward a lower-field resonance at approximately 20.7 ppm [Fig. 2(b), Figs. 5(b) - 5(d) and Table 2]. It is indicated that the isopropyl-methyl group of $l$-menthol in the crystal form and in the solution usually has a less steric
Table $3 \quad{ }^{13} \mathrm{C}$ chemical shifts of all six carbons of $\alpha$ - and $\beta$-CyD (TMS: $0.0 \mathrm{ppm}$ )

\begin{tabular}{|c|c|c|c|c|c|c|}
\hline & \multicolumn{3}{|c|}{$\alpha-\mathrm{CyD}$} & \multicolumn{3}{|c|}{$\beta-\mathrm{CyD}$} \\
\hline & Free & $\begin{array}{l}\text { Physical } \\
\text { mixture }\end{array}$ & $\begin{array}{l}\text { Inclusion } \\
\text { complex }\end{array}$ & Free & $\begin{array}{l}\text { Physical } \\
\text { mixture }\end{array}$ & $\begin{array}{l}\text { Inclusion } \\
\text { complex }\end{array}$ \\
\hline \multirow[t]{5}{*}{$\mathrm{Cl}^{\prime}$} & 103.68 & 103.22 & 103.0 & 104.2 & 104.73 & 104.0 \\
\hline & 102.85 & 102.14 & 101.8 & 103.5 & 103.51 & 102.5 \\
\hline & 98.05 & 100.65 & & 102.5 & 103.16 & \\
\hline & & 98.09 & & 101.7 & 101.64 & \\
\hline & & & & & 100.67 & \\
\hline \multirow{5}{*}{$\begin{array}{l}\mathrm{C} 2^{\prime}, \mathrm{C} 3^{\prime}, \\
\mathrm{C} 5^{\prime}\end{array}$} & 75.64 & 76.71 & 74.7 & 76.4 & 76.71 & 73.6 \\
\hline & 74.77 & 75.52 & 73.7 & 73.9 & 74.15 & 72.9 \\
\hline & 72.51 & 74.17 & 73.1 & 72.9 & 73.35 & \\
\hline & & 72.90 & & & 72.85 & \\
\hline & & 72.05 & & & 71.01 & \\
\hline \multirow[t]{5}{*}{$\mathrm{C} 4^{\prime}$} & 82.96 & 83.17 & 85.3 & 84.5 & 83.23 & 81.7 \\
\hline & 81.92 & 82.79 & 84.0 & 83.6 & 81.87 & 80.1 \\
\hline & 80.53 & 80.59 & 82.1 & 82.5 & 80.61 & \\
\hline & 77.79 & 79.77 & 80.3 & 81.8 & 79.28 & \\
\hline & & 77.85 & & 78.7 & & \\
\hline \multirow[t]{3}{*}{$\mathrm{C} 6^{\prime}$} & 61.66 & 61.74 & 63.4 & 64.0 & 61.4 & 61.6 \\
\hline & 60.97 & 60.56 & 61.2 & 62.2 & 60.7 & \\
\hline & & & & 60.2 & & \\
\hline
\end{tabular}

hinderance, while the group was sterically affected by the narrow space inside $\alpha$-CyD. It is considered that the dihedral angles of the isopropyl-methyl group are closely related to the change in the ${ }^{13} \mathrm{C}$ chemical shifts. ${ }^{49}$ It has been reported that $\alpha$-CyD exhibits very low affinity to menthol enantiomers by gas-liquid chromatography ${ }^{53}$. Cyclic terpenes, $(R)$ and $(S)$ camphor, formed an inclusion complex sandwiched with an $\alpha$-CyD dimer as 1:2 stoichiometry. ${ }^{54}$ There are two binding modes that take polar and equatorial positions of the carbonyl group of camphor inside an $\alpha$-CyD dimer. ${ }^{54}$ Therefore, it may be suggested that $l$-menthol takes a specific arrangement inside the $\alpha-\mathrm{CyD}$, since there is a probability of the formation of $1: 2$ stoichiometry of the $l$-menthol $/ \alpha$-CyD complex prepared by the spray-dried method. Thus, our NMR result indicates that $l$-menthol forms an inclusion complex with a specific arrangement of the guest molecule in the narrow cavity of $\alpha$-CyD dimer.

In the spectrum of the physical mixture with $\alpha$-CyD, the chemical shifts of $l$-menthol were considerably different from those of $l$-menthol crystals [Fig. 2(a) and Fig. 5(c)]. Thus, 


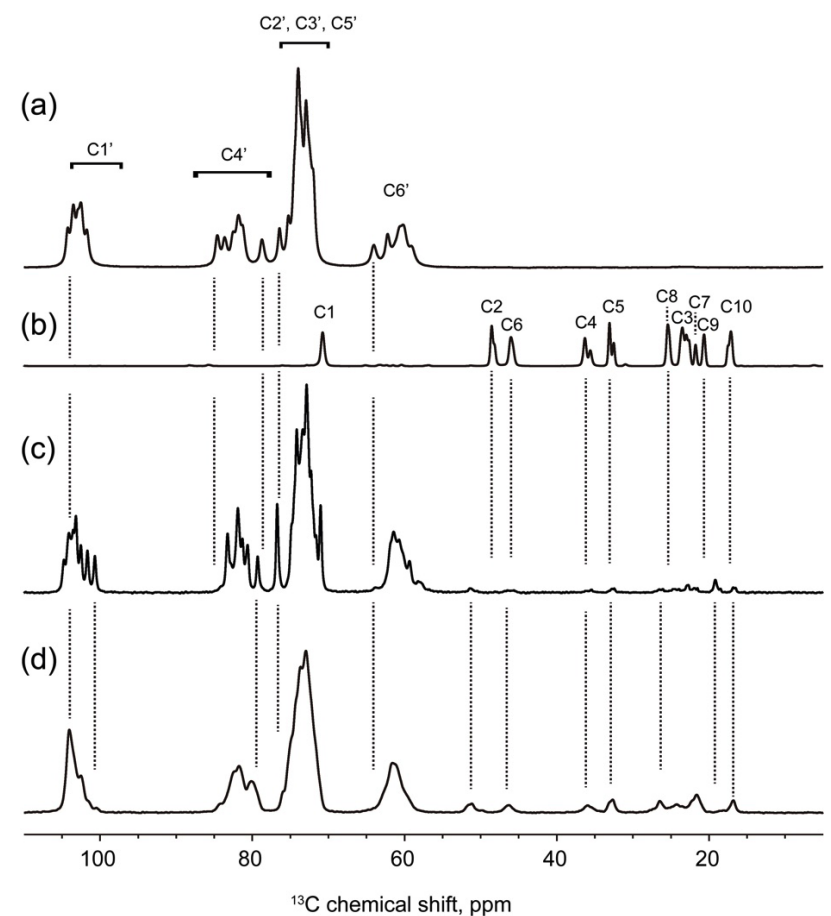

Fig. $6{ }^{13} \mathrm{C}$ CP-MAS NMR spectra of (a) $\beta$-CyD, (b) $l$-menthol crystal, (c) $\beta$-CyD/l-menthol physical mixture, and (d) spray-dried $\beta$-CyD/l-menthol inclusion complex.

the $\mathrm{C}^{\prime}$ and $\mathrm{C}^{\prime}{ }^{\prime}$ signals at 98.5 and $77.4 \mathrm{ppm}$ from $\alpha$-CyD [Figs. 5(a) and 5(c)] correspond to the remaining asymmetric structure in the physical mixture because the $\mathrm{H}_{2} \mathrm{O}-\alpha-\mathrm{CyD}$ complex, which has bound water molecules inside the CyD, give similar resonance positions. ${ }^{28,32}$ Thus, this result indicated that the $\alpha$-CyD structure in the physical mixture was deformed owing to the presence of bound water. It is indicated that $l$-menthol produced an encounter complex with $\alpha$-CyD.

The ${ }^{13} \mathrm{C}$ CP-MAS NMR spectra of $\beta$-CyD, $l$-menthol, the physical mixture of $\beta$-CyD/l-menthol, and the inclusion complex of 10 -wt $\% l$-menthol in $\beta$-CyD were recorded and are shown in Figs. 6(a) - 6(d). In Fig. 6(d), the $\mathrm{Cl}^{\prime}$ and $\mathrm{C} 4^{\prime}$ signals of $\beta$-CyD, which are related to form the asymmetric structure with the water molecule, ${ }^{28,32}$ completely disappeared. It was indicated that the cyclodextrin skeleton was not deformed by internal water in the inclusion complex. Furthermore, because the isopropyl-methyl signals of $\mathrm{C} 9$ and $\mathrm{C} 10$ of $l$-menthol in the inclusion complex appeared at almost the same position as those of its crystal form, the isopropyl-methyl groups inside $\beta$-CyD were not sterically hindered [Figs. 6(b) and 6(d)]. In addition, a comparison of the ${ }^{13} \mathrm{C}$ NMR signals of $l$-menthol in Fig. 7 revealed that the conformation of the isopropyl-methyl groups was completely different between the $\alpha$-CyD and $\beta$-CyD inclusion complex. $l$-Menthol appears to be relatively loosely bound within $\beta$-CyD. $\beta$-CyD has a larger cavity, and allows to form a 1:1 stoichiometry head-to-head complex with $l$-menthol, and $l$-menthol inserts sufficiently in the $\beta$-CyD monomer cavity. ${ }^{55}$ With respects to the thermodynamics of $\alpha$ - and $\beta$-CyD and the size of $l$-menthol, the narrower $\alpha$-CyD should lead to a more constrained inclusion structure, which induces stronger interactions between $\alpha$-CyD and $l$-menthol. ${ }^{56,57}$ Our solid-state NMR results are in good agreement with those observations.

To investigate the symmetry of cyclodextrin forming the inclusion complex, VCD and IR spectra of the $l$-menthol

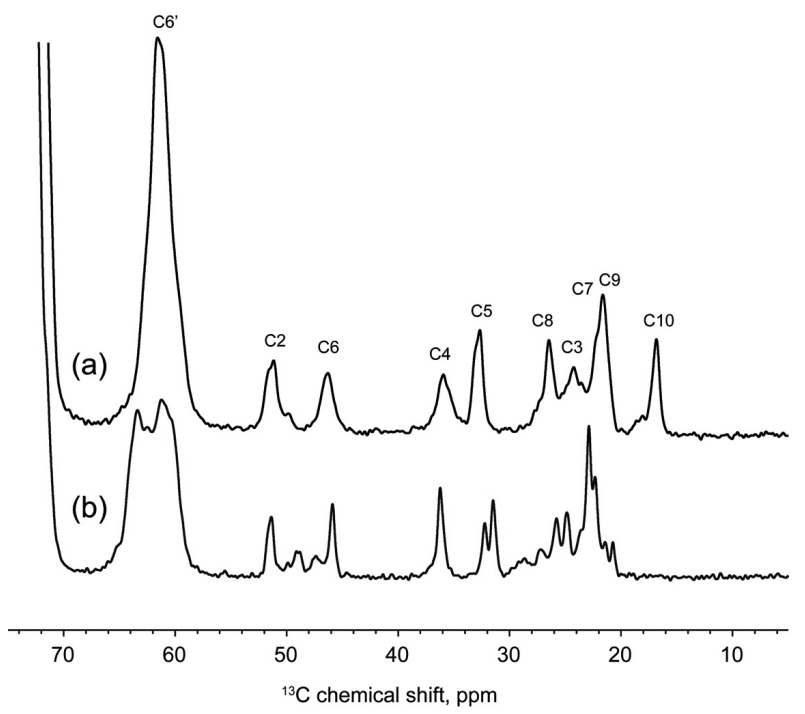

Fig. 7 Comparison of ${ }^{13} \mathrm{C}$ CP-MAS NMR signals of (a) spray-dried $\beta$-CyD/l-menthol and (b) $\alpha$-CyD/l-menthol inclusion complexes in the range of $15-75 \mathrm{ppm}$.

inclusion complex in $\alpha$ - and $\beta$-CyD were recorded and compared with those of $\alpha$ - and $\beta$-CyD powders in the range of $1600-$ $900 \mathrm{~cm}^{-1}$, as shown in Fig. 8. Typical VCD bands of $\alpha$ - and $\beta$-CyD bands, labeled $\mathbf{1}^{\prime}-\mathbf{1 0}$, are shown in Figs. 8(a) and 8(c). It was confirmed that the intensity of those bands was considerably stronger than that of only $\mathrm{KBr}$ pellets. ${ }^{58}$ The intense couplet bands $\mathbf{3}^{\prime}$ and $\mathbf{4}^{\prime}$ of $\alpha$ - and $\beta$-CyD powders appeared as a bi-sign pattern at $1180 \mathrm{~cm}^{-1}(+) / 1154 \mathrm{~cm}^{-1}(-)$, which corresponded to the $\mathrm{C}-\mathrm{O}-\mathrm{C}$ asymmetric stretching mode of the glycoside bonds. In the spectra of inclusion complexes of $\alpha$ - and $\beta$-CyD, the positive VCD band $\mathbf{3}^{\prime}$ completely disappeared, and the intensity of the negative VCD band $4^{\prime}$ completely decreased. Similarly, the VCD bands $\mathbf{9}^{\prime}$ at $993 \mathrm{~cm}^{-1}(-)$ and 10' at $950 \mathrm{~cm}^{-1}(-)$ decreased. The dissymmetry factors of intense VCD bands are less intense in a methyl orange inclusion complex of $\alpha$-CyD because the perturbation by the guest molecule lowers the overall VCD intensity of $\alpha$-CyD..$^{59,60}$ In our VCD results, the markedly different intensities of bands $\mathbf{3}^{\prime}$ and $4^{\prime}$ indicated that $l$-menthol is effectively bound in the cavity of both $\alpha$ - and $\beta$-CyD and perturbs the host. This agrees with the disappearance of ${ }^{13} \mathrm{C}$ NMR signals of $\mathrm{Cl}^{\prime}$ and $\mathrm{C}^{\prime}$ owing to the dissymmetric bonds of cyclodextrins (Fig. 4). Furthermore, only in the VCD spectrum of the $\alpha$-CyD inclusion complex, the intensity of band $\mathbf{8}^{\prime}$ at $1023 \mathrm{~cm}^{-1}(-)$, which corresponds to the $\mathrm{C}-\mathrm{C}$ and $\mathrm{C}-\mathrm{O}$ stretching modes in $\mathrm{CyD}$, was considerably decreased. The intensity of band $\mathbf{7}^{\prime}$ at $1043 \mathrm{~cm}^{-1}$ also decreased, but was not assigned to a specific vibrational mode of CyDs. The original intense VCD bands $\mathbf{1 0}$ and $\mathbf{1 1}$ of $l$-menthol may contribute to the band intensities of $\mathbf{7}^{\prime}$ and $\mathbf{8}^{\prime}$ of $\alpha$-CyD in the same region [Fig. 8(a)], although the VCD bands of less abundant $l$-menthol may be part of intense CyD bands. Specifically, it is considered that the band intensities of $\mathbf{1 0}$ and 11 corresponding to the $\mathrm{C} 1-\mathrm{O}$ stretching mode and the cyclohexane ring deformation of menthol resulted from the tight incorporation of menthol into the hydrophobic cavity of $\alpha$-CyD. This concept is consistent with the observation of separated $\mathrm{C} 2$, C4, and C5 NMR signals and the disappearance of C10 signals in the NMR spectrum of the $l$-menthol $/ \alpha-\mathrm{CyD}$ inclusion complex [Fig. 6(b)].

The combined analysis of solid-state NMR and VCD can be 
(a)

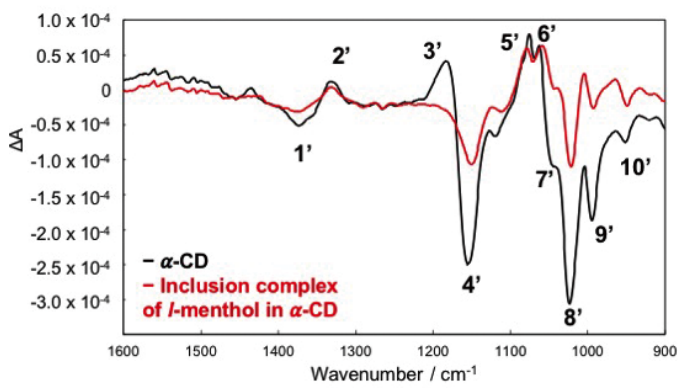

(b)

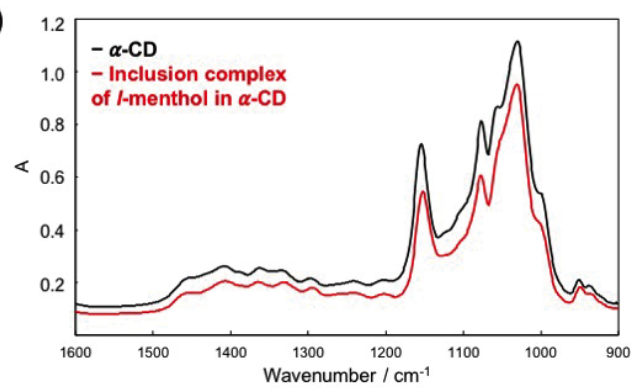

(c)

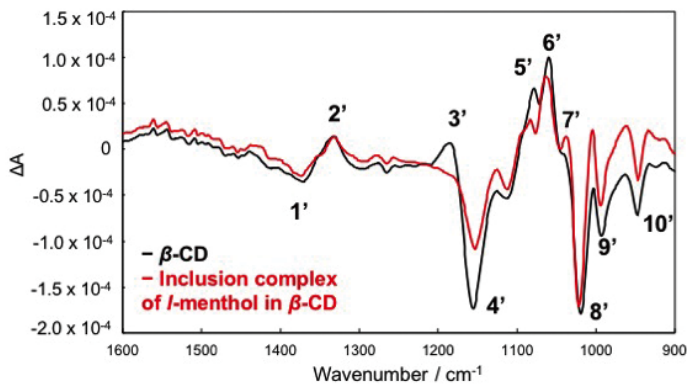

(d)

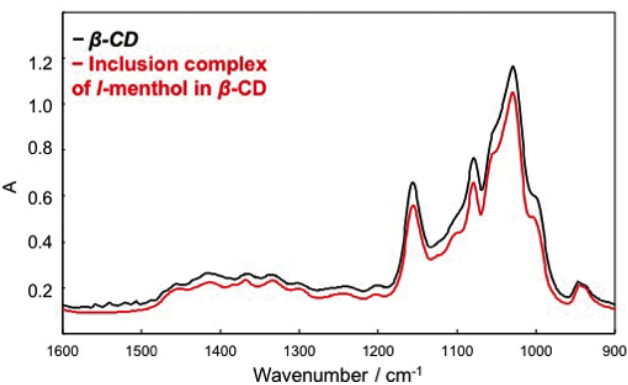

Fig. 8 (a) VCD and (b) IR spectra of $\alpha$-CyD (black) and $\alpha$-CyD/l-menthol inclusion complex (red). (c) and (d) IR spectra of $\beta$-CyD (black) and $\beta$-CyD/l-menthol inclusion complex (red).

useful to investigate a solid-state structure of a cyclodextrinflavor inclusion complex, if there are hardly serious signal overlapping between the host and guest molecules. These technologies are important tools to support the design of new attractive flavor materials and to understand the characteristics of an inclusion complex.

\section{Conclusions}

In this study, we demonstrate that the combined analysis of solid-state NMR and VCD is a powerful approach that allows one to investigate the structure of flavor compound inclusion complexes in the solid-state. To characterize the structure of $l$-menthol inclusion complexes in $\alpha$ - and $\beta$-CyD in the solidstate, ${ }^{13} \mathrm{C}$ CP-MAS NMR and VCD experiments of spray-dried samples were conducted. We showed the different structural aspects of $l$-menthol and $\mathrm{CyD}$ in the inclusion complexes between $\alpha$ - and $\beta$-CyD by analyzing the characteristic NMR signals and the VCD bands. Consequently, we found that the structure of included $l$-menthol was different for $\alpha$ - and $\beta$-CyD in the spray-dried inclusion complexes.

\section{Acknowledgements}

This work was partly supported by Industry-University Collaboration Research Start-Up Grants from Yokohama National University to I. K. and JST MIRAI grants to I. K. and H. S. (JPMJMI18GC).

\section{References}

1. A. J. Parades, C. M. Ascencio, L. J. Manuel, D. A. Allemandi, and S. D. Palma, J. Food Bioeng. Nanoprocessing, 2016, 1, 56.

2. M. Saifullah, M. R. I. Shishir, R. Ferdowsi, M. R. T
Rahman, and Q. V. Vuong, Trends Food Sci. Technol., 2019, 86, 230.

3. M. Wang, T. Doi, and D. J. McClements, Food Res. Int., 2019, 119,6 .

4. R. D. Sangolkar, D. K. Kawadkar, B. A. Bhanvase, S. H. Sonawane, and I. Potoroko, J. Food Process Eng., 2019, 42, e13269.

5. T. A. Reineccius, G. A. Reineccius, and T. L. Peppard, J. Food Sci., 2004, 69, FCT58.

6. A. Kant, R. S. T. Linforth, J. Hort, and A. J. Taylor, J. Agric. Food Chem., 2004, 52, 2028.

7. M. V. Rekharsky and Y. Inoue, Chem. Rev., 1998, 98, 1875.

8. G. Crini, Chem. Rev., 2014, 114, 10940.

9. H. Shiga, H. Yoshii, T. Nishiyama, T. Furuta, P. Forssele, K. Poutanen, and P. Linko, Drying Tech. Int. J., 2007, 19, 1385 .

10. A. Popat, S. Karmakar, S. Jambhrunkar, C. Xu, and C. Yu, Colloids Surf., B, 2014, 117, 520.

11. T. Loftsson, P. Jarho, M. Masson, and T. Jarvinen, Expert Opin. Drug Deliv., 2005, 2, 335.

12. R. Breslow and S. D. Dong, Chem. Rev., 1998, 98, 1997.

13. V. A. Marcolino, G. M. Zanin, L. R. Durrant, M. D. T. Benassi, and G. Matioli, J. Agric. Food Chem., 2011, 59, 3348.

14. G. Wenz, M. B. Steinbrunn, and K. Landfester, Tetrahedron, 1997, 53, 15575.

15. H. J. Buschmann and E. Schollmeyer, J. Cosmet. Sci., 2002, 53, 185 .

16. R. B. Croteau, E. M. Davis, K. L. Ringer, and M. R. Wildung, Naturwissenschaften, 2005, 92, 562.

17. G. P. P. Kamatou, I. Vermaak, A. M. Viljoen, and B. M. Lawrence, Phytochemistry, 2013, 96, 15.

18. S. Akutagawa, Top. Catal., 1997, 4, 271.

19. R. Noyori, Adv. Synth. Catal., 2003, 345, 15.

20. A. F. Trasarti, A. J. Marchi, and C. R. Apesteguia, J. Catal., 2004, 224, 484.

21. X. D. Liu, T. Furuta, H. Yoshii, P. Linko, and W. J. 
Coumans, Biosci., Biotechnol., Biochem., 2000, 64, 1608.

22. G. Zhu, Z. Xiao, G. Zhu, Rujunzhou, and Y. Niu, Pol. J. Chem. Technol., 2016, 18, 110.

23. G. Zhu, G. Zhu, and Z. Xiao, J. Inclusion Phenom. Macrocyclic Chem., 2019, 95, 17.

24. Z. I. Yildiz, A. Celebioglu, M. E. L. Kilic, E. Durgun, and T. Uyar, J. Food. Eng., 2018, 224, 27.

25. L. Y. Yang, D. X. Wei, M. Xu, Y. F. Yao, and Q. Chen, Angew. Chem., Int. Ed., 2014, 53, 3631.

26. A. Naito, I. Kawamura, and N. Javkhlantugs, "Recent Solid-State NMR Studies of Membrane-Bound Peptides and Proteins", Annu. Rep. NMR Spectrosc., 2015, Vol. 86, Chap. 5, Elsevier, 333.

27. N. Kanai, N. Yoshihara, and I. Kawamura, Biosci., Biotechnol., Biochem., 2019, 83, 803.

28. H. Saitô, G. Izumi, T. Mamizuka, S. Suzuki, and R. Tabeta, J. Chem. Soc., Chem. Commun., 1982, 24, 1386

29. S. Lai, E. Locci, A. Piras, S. Porcedda, A. Lai, and B. Marongiu, Carbohydr. Res., 2003, 338, 2227.

30. B. T. Ho and B. R. Bhandrai, J. Agric. Food Chem., 2016, 64, 3318

31. J. Priotti, A. Gracia, D. Leonardi, M. J. Ferreira, M. C. Lamas, and T. G. Nunes, Mater. Sci. Eng., C, 2018, 92, 694.

32. H. Saitô, Magn. Reson. Chem., 1986, 24, 835.

33. H. Saitô and R. Tabeta, Chem. Lett., 1981, 10, 713.

34. L. G. Felippe, J. M. Batista Jr., D. C. Baldoqui, I. R. Nascimento, M. J. Kato, Y. He, L. A. Nafie, and M. Furlan, Org. Biomol. Chem., 2012, 10, 4208.

35. H. Sato, H. Uno, and H. Nakano, Dalton Trans., 2011, 40, 1332.

36. C. Kiske, A. D. Riegel, R. Hopf, A. Kvindt, I. Poplacean, T. Taniguchi, M. M. M. Swamy, K. Monde, W. Eisenreich, and K. H. Engel, J. Agric. Food Chem., 2019, 67, 1187.

37. D. Kurouski, Anal. Chim. Acta, 2017, 990, 54.

38. D. Kurouski, J. D. Handen, R. K. Dukor, L. A. Nafie, and I K. Lednev, Chem. Commun., 2015, 51, 89.

39. H. Sato, I. Kawamura, A. Yamagishi, and F. Sato, Chem. Lett., 2017, 46, 449.

40. H. Sato, T. Yajima, and A. Yamagishi, Chem. Commun., 2011, 47, 3736.

41. B. Mijiddorj, S. Kaneda, H. Sato, Y. Kitahashi, N.
Javkhlantugs, A. Naito, K. Ueda, and I. Kawamura, Biochim. Biophys. Acta, Proteins Proteomics, 2018, 1768, 789

42. D. D. Laws, H. M. L. Bitter, and A. Jerschow, Angew. Chem., Int. Ed., 2002, 41, 3096.

43. H. Sato, Phys. Chem. Chem. Phys., 2020, 22, 7671.

44. H. Akustu, Biochim. Biophys. Acta, Biomembr., 2020, 1862 , 183352.

45. Y. Ozawa, H. Sato, Y. Kayano, N. Yamaki, Y. Izato, A. Miyake, A. Naito, and I. Kawamura, Phys. Chem. Chem. Phys., 2019, 21, 10879.

46. H. M. Jensen, F. H. Larsen, and S. B. Engelsen, Natural Products From Marine Algae, 2015, 1308, 347.

47. B. M. Fung, A. K. Khitrin, and K. Ermolaev, J. Magn Reson., 2000, 142, 97.

48. Y. Senda and S. Imaizumi, Tetrahedron, 1975, 31, 2905.

49. J. Härtner and U. M. Reinscheid, J. Mol. Struct., 2008, 872 , 145.

50. J. R. A. Moreno, F. P. Urena, and J. J. L. Gonzalez, Struct Chem., 2013, 24, 671.

51. J. L. McCann, A. Rauk, and H. Wieser, Can. J. Chem., 1998, 76, 274.

52. J. Shen, Y. Li, and H. Izumi, J. Chem. Theory Comput., 2012, 8, 2763.

53. M. Asztemborska, D. Sybilska, R. Nowakowski, and G. Perez, J. Chromatogr., A, 2003, 1010, 233.

54. A. Kokkinou, F. Tsorteki, M. Karpusas, A. Papakryiakou, K. Bethanis, and D. Mentzafos, Carbohydr. Res., 2010, $345,1034$.

55. M. Ceborska, M. Asztemborska, and J. Lipkowski, Chem. Phys. Lett., 2012, 553, 64.

56. M. Kfoury, D. Landy, and S. Fourmentin, Molecules, 2018 , 23, 1204.

57. G. Astray, J. C. Mejuto, J. Morales, R. Rial-Otero, and J. Simal-Gandara, Food Res. Int., 2010, 43, 1212.

58. I. Kawamura and H. Sato, Anal. Biochem., 2019, 580, 14.

59. P. K. Bose and P. L. Polavarapu, Carbohydr. Res., 2000, 32, 63.

60. V. Setnieka, M. Urbanova, V. Kral, and K. Volka, Spectrochim. Acta, Part A, 2002, 2983. 